\title{
Perilaku Masyarakat dalam Menerapkan Protokol Kesehatan Covid-19 di Kelurahan Tangkerang Barat Kota Pekanbaru
}

\author{
Namira Febriana, Fatmariza \\ Prodi Pendidikan Pancasila dan Kewarganegaraan \\ FIS Universitas Negeri Padang \\ E-mail: namiraafebrianaa@gmail.com
}

\begin{abstract}
ABSTRAK
Artikel ini bertujuan untuk menganalisis bentuk-bentuk perilaku masyarakat terhadap protokol kesehatan di masa pandemi Covid-19 serta untuk mengidentifikasi faktor penyebab masyarakat mematuhi ataupun tidak mematuhi aturan protokol kesehatan di masa pandemi Covid-19 tersebut. Metodologi yang digunakan dalam penelitian ini adalah kualitatif dengan pendekatan deskriptif. Penentuan informan dalam penelitian ini menggunakan teknik purposive sampling, dengan teknik pengumpulan datanya yaitu observasi, wawancara, dan dokumentasi. Uji keabsahan data menggunakan teknik triangulasi teknik. Setelah data berhasil diperoleh, kemudian data dianalisis dengan menggunakan teknik analisis data yang terdiri dari reduksi data, display data dan penarikan kesimpulan. Hasil penelitian ini menunjukkan bahwa terdapat dua wujud perilaku masyarakat dalam menjalakan protokol kesehatan, diantara yang pertama yaitu wujud ketidakpatuhan yang terdiri dari tidak menggunakan masker, berkerumunan, tidak menyediakan saran tempat cuci tangan di tempat umum maupun rumah dan tidak adanya pengaturan jaga jarak. Kemudian yang kedua yaitu wujud kepatuhan yang terdiri dari menggunakan masker, penyediaan sarana cuci tangan ditempat umum maupun rumah, serta terdapatnya pengaturan jaga jarak. Hal tersebut terjadi karena adanya beberapa faktor internal dan eksternal yang tedapat dalam masyarakat tersebut.
\end{abstract}

Kata Kunci: perilaku, protokol kesehatan, Tangkerang Barat

\section{ABSTRACT}

This article aims to analyze the forms of behavior of the community to the protocol of health in the pandemic Covid-19 as well as to identify the factors that cause people adhere or not adhere to the rules of the protocol health in the pandemic Covid-19. The methodology used in this research is qualitative with descriptive approach. Determination of informants in this study using purposive sampling technique, with data collection techniques are observation, interview, and documentation. Test the validity of data using triangulation techniques engineering. After the data is successfully obtained, then the data were analyzed by using the technique of data analysis consists of 
data reduction, data display and conclusion. The results of this study indicate that there are two form of people's behavior in the run protocol health, among which the first is a form of non-compliance which consists of not using a mask, berkerumunan, does not provide advice of handwashing facilities in public areas and homes and the absence of settings keep your distance. Then the second is a form of compliance that consists of using a mask, the provision of means of washing hands in a public place or home, as well as the presence of the settings.keep your distance. This happens due to the presence of some internal and external factors that are artifacts in the community.

\section{Keywords: behavior, health protocol, Tangkerang Barat}

\section{PENDAHULUAN}

Pada akhir tahun 2019, seluruh penjuru dunia ditimpa musibah dengan munculnya sebuah virus baru yang bernama Covid-19. Untuk menghindari penyebaran virus tersebut berbagai aturan dikeluarkan oleh pemerintahan Indonesia seperti "Keputusan Menteri Kesehatan Republik Indonesia Nomor Hk.01.07/Menkes/382/2020 Tentang Protokol Kesehatan Bagi Masyarakat Di Tempat Dan Fasilitas Umum Dalam Rangka Pencegahan Dan Pengendalian Corona Virus Disease 2019 (Covid-19)". Kebijakan ini dibuat agar masyarakat tetap bisa menjalankan hidupnya namun tetap dalam pencegahan agar terhindar dari virus tersebut. Kebijakan tersebut antara lain yaitu wajib menggunakan masker saat berpergian, menjaga jarak dengan orang lain, menghindari kerumunan, selalu mencuci tangan dan beberapa aturan lainnya.

Dengan adanya kebijakan wajib patuh terhadap protokol kesehatan tersebut, tentu menjadi adaptasi yang besar bagi masyarakat. Karena seperti yang kita ketahui sebelum adanya pandemi ini masyarakat bebas melakukan kegiatannya tanpa dibatasi dengan aturan protokol kesehatan. Karena adanya adaptasi ini, tentu menimbulkan berbagai macam perilaku masyarakat terhadap aturan protokol kesehatan tersebut. Dimana terdapat masyarakat yang berperilaku mematuhi protokol kesehatan dan ada yang tidak berperilaku mematuhi protokol tersebut. Tentu setiap perilaku yang dipilih oleh masyarakat tersebut dalam menjalankan protokol kesehatan memiliki faktor-faktor dan alasannya masing-masing. Menurut Arifin (2015) perilaku manusia adalah segala bentuk wujud pengetahuan, sikap, serta tindakan yang dihasilkan dari adanya pengalaman dan interaksi manusia tersebut terhadap lingkungannya. Perilaku tersebut merupakan reaksi dari seorang individu terhadap stimulusnya, baik yang berasal dari luar maupun dari dalam dirinya tersebut. Dari hal tersebut didapatkan bahwa reaksi manusia digolongkan kedalam dua bentuk yaitu dalam bentuk pasif (tanpa 
tindakan nyata/pasif) dan dalam bentuk aktif (dengan tindakan konkret).

Sebelum penelitian ini dilakukan, sudah terdapat beberapa penelitian yang meneliti terkait perilaku manusia dan protokol kesehatan. Beberapa penelitian tersebut diantaranya yaitu Anhusadar (2021) mengemukakan bahwasannya dalam lingkungan keluarga selama adanya pandemi Covid-19, perilaku hidup bersih dan sehat pada anak usia dini sudah terlaksanakan dengan baik. Banyak orang tua yang sudah mengajarkan kepada anaknya terkait hidup bersih tersebut. Selain itu juga dipengaruhi karena rata-rata orang tua memiliki riwayat pendidikan yang cukup baik. Selanjutnya menurut Purnamasari, et al (2020) menyebutkan bahwasannya tingkat pengetahuan masyarakat Wonosobo dikategorikan tinggi dan perilaku masyarakat Wonosobo tentang pencegahan dan penularan Covid-19 dikategorikan baik. Kemudian menurut Afro, at al (2020) bahwasannya mayoritas individu memiliki persepsi manfaat yang positif, maksudnya disini setiap individu sudah cukup menyadari manfaat mematuhi protokol kesehatan tersebut. Akan tetapi mayoritas individu juga memiliki persepsi hambatan positif. Dimana menyadari bahwa terdapat hambatan yang terjadi jika mematuhi protokol kesehatan tersebut.

Selain dari penelitian terdahulu yang sudah ada, penelitian ini juga didukung dari hasil observasi lapangan yang ditemukan. Dimana bahwa dalam penerapan protokol kesehatan masa pandemi Covid-19 di kalangan masyarakat Kelurahan Tangkerang Barat Kota Pekanbaru, masih cukup banyak masyarakat yang tidak begitu memperdulikan peraturan protokol kesehatan tersebut. Berdasarkan dari hasil penelitian terdahulu dan observasi lapangan dalam penelitian ini, peneliti ingin melakukan penelitian terhadap perilaku masyarakat terhadap protokol kesehatan yang memfokuskan pada wujud serta faktor penyebab masyarakat tidak mematuhi dan mematuhi aturan protokol kesehatan tersebut. Penelitian ini diharapkan menambah pengetahuan serta wawasan masyarakat terhadap pentingnya protokol kesehatan di era pandemi Covid-19, serta dapat menjadi pedoman bagi masyarakat untuk meninggalkan perilaku tidak menerapkan protokol kesehatan dan memilih untuk berperilaku menerapkan protokol kesehatan dalam kehidupan sehari-harinya, sehingga dapat bersama-sama mencegah penyebaran Covid-19.

\section{METODE PENELITIAN}

Penelitian ini merupakan penelitian kualitatif dengan pendekatan deskriptif. Informan dipilih secara purposive sampling. Informan tersebut terdiri dari Lurah, Bhabinsa, Bhabinkabtimnas, Ketua RW 10, Ketua RT 02/10, dan beberapa masyarakat di Kelurahan Tangkerang Barat Kota Pekanbaru. Data diperoleh dengan menggunakan beberapa teknik yaitu, observasi, wawancara dan dokumentasi. Uji keabsahan 
data dalam penelitian ini dilakukan dengan menggunakan triangulasi teknik, dan penganalisaan data menggunakan beberapa tahapan yaitu reduksi data, display data, dan penarikan kesimpulan yang diharapkan dapat menjawab masalah yang sudah dirumuskan sejak awal.

\section{HASIL DAN PEMBAHASAN}

Dalam menjalankan aktifitas kehidupan sehari-hari, saat ini masyarakat dituntut untuk menegakkan protokol kesehatan yang berguna untuk meminimalisir menyebaran virus covid-19 yang sangat membahayakan bagi banyak orang. Memang dalam menjalankan kehidupan saat ini masyarakat dituntut untuk mampu merubah perilakunya yang biasanya dapat berkegiatan bebas namun kini menjadi terbatas. Dari hasil temuan yang peneliti peroleh dilapangan ternyata terdapat dua perilaku masyarakat dalam menjalankan protokol kesehatan, diantara yaitu ada yang berperilaku tidak patuh dan ada yang berperilaku patuh terhadap aturan protokol kesehatan tersebut.

Ketidakpatuhan dan kepatuhan masyarakat tersebut dapat dilihat dalam wujud perilaku yang mereka lakukan. Wujud perilaku masyarakat yang pertama yaitu ketidakpatuhan. Dimana hal tersebut dapat terlihat karena terdapat masyarakat saat bepergian tidak menggunakan masker, berkerumunan, tidak menerapkan penyediaan sarana cuci tangan ditempat umum ataupun didepan rumah, serta tidak menyedikan pembatasan jaga jarak di tempat umum. Kemudian wujud kepatuhan masyarakat terlihat dengan adanya masyarakat yang menerapkan penggunaan masker saat bepergian keluar rumah, menerapkan menyediaan sarana cuci tangan ditempat umum maupun didepan rumah, serta penyediaan jaga jarak di tempat umum yang mayoritas merupakan sarana ibadah umat islam yaitu masjid. Hal ini dapat dilihat dalam tabel data sebagai berikut:

\begin{tabular}{|r|l|l|l|}
\hline No. & Wujud Perilaku & Tidak Mematuhi & Mematuhi \\
\hline 1. & $\begin{array}{l}\text { Tidak } \\
\text { Menggunakan } \\
\text { Masker }\end{array}$ & 10 Informan & 5 Informan \\
\hline 2. & Berkerumun & $\begin{array}{l}\text { 10 Tempat Umum: 3 tempat makan, } \\
\text { coffee shop, 1 toserba, 1 warung, 1 } \\
\text { store HP, dan 1 penjual minuman } \\
\text { kaki lima. }\end{array}$ & $\begin{array}{l}\text { Tidak ada yang } \\
\text { mematuhi }\end{array}$ \\
\hline 3. & $\begin{array}{l}\text { Tidak Menyediakan } \\
\text { Sarana Cuci } \\
\text { Tangan }\end{array}$ & $\begin{array}{l}\text { 31 Rumah dan 11 Tempat Umum, } \\
\text { yang merupakan coffeshop dan } \\
\text { tempat makan. }\end{array}$ & $\begin{array}{l}\text { 3 Rumah dan 4 } \\
\text { Tempat Umum }\end{array}$ \\
\hline 4. & $\begin{array}{l}\text { Tidak Terdapat } \\
\text { Pengaturan Jaga } \\
\text { Jarak }\end{array}$ & $\begin{array}{l}6 \text { Tempat Umum yang diantaranya } \\
\text { tempat makan dan coffeshop. }\end{array}$ & $\begin{array}{l}\text { 3 Tempat yaitu } \\
\text { Sarana Ibadah } \\
\text { Umat Islam }\end{array}$ \\
\hline
\end{tabular}


Pada dasarnya setiap manusia memiliki hak untuk memilih perbuatan yang akan mereka lakukan. Seperti yang peneliti temukan terdapat beberapa masyarakat di kelurahan ini yang memilih untuk tidak mematuhi aturan protokol kesehatan. Hal ini sejalan dengan teori yang dikemukakan oleh Travis Hirschi (Siahaan \& Margareth, 2019) yang menyatakan bahwa setiap individu itu memiliki kecenderungan untuk tidak patuh terhadap aturan. Dalam penerapan aturan protokol kesehatan, peneliti juga menemukan bahwa terdapat masyarakat di kelurahan ini yang masih mematuhi aturan tersebut. Masyarakat yang peneliti temui memilih menaati aturan protokol kesehatan karena memang mereka ingin dan patuh terhadap aturan serta merasa memiliki tanggung jawab untuk melindungi diri dan orang disekitar mereka. Hal ini dibuktikan dengan mereka malaksanakan aturan tersebut berdasarkan kemauan mereka. Ini sesuai dengan teori kontrol sosial yang dipaparkan oleh Travis Hirschi (Siahaan \& Margareth, 2019) dimana kepatuhan serta tanggung jawab merupakan bagian utama dalam kontrol sosial internal yang memiliki fungsi untuk mengendalikan perilaku individu. Dari hasil temuan penelitian ini, ditemukan bahwa terdapat faktor-faktor yang mempengaruhi masyarakat dalam menjalankan protokol kesehatan ataupun tidak. Dari segi ketidakpatuhan tersebut terdapat ada dua faktor yang mempengaruhinya yaitu internal dan eksternal.

\section{Faktor Internal: Keinginan Diri Sendiri}

Berdasarkan dari tanggapan informan yang memilih untuk tidak menerapkan protokol kesehatan dikarenakan terlupakan dan terasa lemas, panas bahkan sesak nafas saat penggunaan masker. Kemudia informan tidak menjalankan protokol kesehatan karena merasa orang yang meraka dijumpai adalah orang terdekat ataupun orang yang berada di sekeliling lingkungan tempat tinggal mereka.

\section{Faktor eksternal: Faktor Lingkungan dan keluarga}

Faktor lingkungan daerah tempat tinggal serta lingkungan pergaulan juga sangat berpengaruh, karena ditemukan bahwa kurangnya rasa untuk saling mengingatkan antar satu dengan yang lainnya, sehingga membuat perilaku tidak menerapkan protokol kesehaan tersebut menjadi hal yang biasa. Lingkungan keluarga berpengaruh terhadap perilaku individu dalam menjalankan protokol kesehatan. Terbukti dengan adanya pernyataan masyarakat yang mengatakan bahwa, dalam keluarganya tidak ada saling mengingatkan untuk menerapkan protokol kesehatan, bahkan ada yang sama-sama berpikiran bahwa protokol kesehatan tersebut tidak perlu dijalankan. Oleh sebab itu semakin kurang rasa keinginan seseorang untuk menjalankan aturan protokol kesehatan tersebut.

Masyarakat yang memilih untuk berperilaku patuh terhadap protokol kesehatan juga memiliki beberapa faktor penyebab sebagai berikut. 


\section{Faktor internal: Faktor Kemauan Diri Sendiri}

Dalam menjalankan aturan protokol kesehatan, cukup banyak yang mengatakan bahwa berperilaku menerapkan protokol kesehatan didasari atas dasar kemauan diri sendiri. Kemauan tersebut didukung karena ingin menjaga diri sendiri serta keluarga agar terhindar dari Covid19. Mereka juga memahami bahwa virus ini cukup membayakan karena dibuktikan dengan banyaknya korban yang meninggal dunia.

\section{Faktor eksternal: Faktor Paksaan dan Keluarga}

Masyarakat yang tidak begitu menerapkan protokol kesehatan mengakui bahwa menajalankan protokol kesehatan tersebut apabila mengunjungi tempat-tempat yang memiliki pengawasan secara khusus terhadap protokol kesehatan, seperti mall, bank, kantorkantor dan lain sebagainya. Perilaku tersebut bukan perilaku yang didasari atas kemauan pribadi, melainkan karena adanya kebutuhan serta suruhan yang membuat mereka menerapkan protokol kesehatan tersebut. Dalam menjalankan protokol kesehatan di kehidupan sehariharinya, ternyata cukup banyak masyarakat yang menerapkan aturan tersebut karena adanya figure keluarga yang selalu saling mengingatkan terhadap protokol kesehatan.

Selain beberapa faktor diatas, terdapat faktor pendukung lainnya yang membuat masyarakat tersebut tidak mamatuhi ataupun mematuhi aturan protokol kesehatan tersebut. Pertama, faktor Pendidikan. Informan yang memiliki tingkat pendidikan rendah seperti SD dan SMP cenderung untuk menerapkan perilaku tidak patuh terhadap protokol kesehatan. Sedangkan masyarakat yang berpendidikan SMA hingga perguruan tinggi cenderung untuk menerapkan perilaku patuh terhadap protokol kesehatan. Kedua, faktor Jenis Kelamin dimana mayoritas informan yang berjenis kelamin laki-laki yang cenderung tidak patuh terhadap protokol kesehatan sementara informan berjenis kelamin perempuan cenderung patuh. Ketiga, faktor Pekerjaan, dimana mayoritas informan yang bekerja sebagai wirausaha yang berperilaku tidak menjalankan aturan protokol kesehatan. Keempat, faktor agama yaitu terdapat beberapa masyarakat yang beragama islam mengunjungi tempat beribadah mereka, namun tetap dalam penerapan aturan tersebut. Dapat dilihat bahwa mereka menyadari untuk dapat sholat berjamaah di dalam masjid harus menerapkan aturan tersebut, agar mereka dapat melaksanakan sholat secara berjamaah.

\section{KESIMPULAN}

Berdasarkan dari hasil penelitian serta pembahasan terkait wujud perilaku masyarakat di Kelurahan Tangkerang Barat Kota Pekanbaru dalam menerapkan protokol kesehatan di era pandemi Covid-19, maka dapat ditarik kesimpulan bahwa dalam penerapan protokol kesehatan ditemukan berbagai bentuk perilaku masyarakat di Kelurahan Tangkerang Barat Kota Pekanbaru, diantaranya yaitu ada 
yang berperilaku tidak mematuhi dan ada yang mematuhi aturan protokol kesehatan. Ada beberapa faktor yang menjadi penyebab masyarakat berperilaku tidak mematuhi dan mematuhi aturan protokol kesehatan tersebut, yaitu terbagi atas faktor internal dan eksternal. Selain itu terdapat juga faktor pendukung lainnya yang membuat masyarakat tidak mematuhi dan mematuhi aturan protokol kesehatan, diantaranya yaitu faktor pendidikan, jenis kelamin, pekerjaan dan agama.

\section{DAFTAR PUSTAKA}

Arifin, B. S. (2015). Psikologi Sosial. Bandung: Pustaka Setia

Anhusadar, L. O. (2021): Jurnal Pendidikan Anak Usia Dini Penerapan Perilaku Hidup Bersih dan Sehat Anak Usia Dini di Tengah Pandemi Covid 19 Jurnal Obsesi. 5(1), 463-475

Afro, R. C. (2020). Analisis Faktor Yang Mempengaruhi Kepatuhan Terhadap Protokol Kesehatan Saat Pandemi Covid-19 Pada Masyarakat Jawa Timur: Pendekatan Health Belief Model. Journal of Community Mental Health and Public Policy, 3(1), 1-10

Purnama I \& Raharyani A.E. (2020). Tingkat pengetahuan dan perilaku masyarakat Kabupaten Wonosobo tentang Covid-19. Jurnal Ilmiah Kesehatan 2020. Mei, 33-42

Moleong, L. J. (2006). Metodologi Penelitian Kualitatif Edisi Revisi. Bandung: Remaja Rosdakarya

Sugiono. (2015). Metodologi Penelitian Pendidikan (Pendekatan Kuantitatif, Kualitatif, dan R\&D). Bandung: Alfabet

Siahaan, S. B., \& Margareth, M. (2019). Kajian Perilaku Seks Bebas dalam Perspektif Teori Kontrol Sosial Travis Hirschi Di Wilayah Beji Depok. Jurnal Anomie, 1(1)

Keputusan Menteri Kesehatan Republik Indonesia Nomor Hk.01.07/Menkes/382/2020 Tentang Protokol Kesehatan Bagi Masyarakat di Tempat Dan Fasilitas Umum dalam Rangka Pencegahan dan Pengendalian Corona Virus Disease 2019 (Covid19) 